\author{
В. А. Щербаков \\ Прокуратура г. Новоалтайска Алтайского края, \\ г. Новоалтайск, Российская Федерация
}

\title{
СОСТЯЗАТЕЛЬНОСТЬ УГОЛОВНОГО СУДОПРОИЗВОДСТВА: РОЛЬ СУДА В ЕЕ ОБЕСПЕЧЕНИИ
}

\begin{abstract}
АНнотАция. Статья посвящена анализу существующих в юридической литературе взглядов ученых на природу положения суда в уголовном судопроизводстве, который показал неоднозначность подходов к определению его статуса в условиях реализации принципа состязательности. Рассматриваются наиболее дискуссионные в настоящее время вопросы, касающиеся правомерности отнесения суда к субъектам доказывания, установления степени и пределов его активности в состязательном судопроизводстве и допустимости в связи с этим осуществления судом собирания доказательств по собственной инициативе. Аргументируется вывод о том, что для последовательной реализации состязательности уголовного судопроизводства единственным основанием осуществления судом собирания доказательств должно быть наличие ходатайства о том сторон, поэтому инициирование производства судебных действий в целях получения новых доказательств должно быть задачей сторон. Активность суда в проведении судебных действий должна быть обусловлена исключительно необходимостью проверки и оценки доказательств. Предлагается внесение изменений в Уголовно-процессуальный кодекс РФ для устранения имеющей место в настоящее время неопределенности статуса суда.
\end{abstract}

кЛючЕВЫЕ слОВА. Состязательность; активность суда; доказывание; собирание доказательств.

ИНФОРМАЦИЯ О СТАТЬЕ. Дата поступления 26 августа 2016 г.; дата принятия к печати 13 сентября 2016 г.; дата онлайн-размещения 30 сентября 2016 г.

\author{
V. A. Shcherbakov \\ Novoaltaisk Prosecutor's Office of Altai Territory, \\ Novosibirsk, Russian Federation
}

\section{ADVERSARY SYSTEM OF CRIMINAL PROCEEDINGS: COURT'S ROLE IN ITS PROVISION}

\begin{abstract}
The article is devoted to analyzing scientists' views of the nature of the court position in criminal proceedings, existing in legal literature, which shows the ambiguity of approaches to defining its status in terms of implementing the adversarial system principle. It considers the most currently controversial issues concerning the legality of referring the court to the subjects of proof, establishing the extent and the limits of its activeness in adversarial proceedings and admissibility, in this regard, of the court's performance in gathering the evidence on its own initiative. It argues the conclusion that for consistent implementation of adversarial criminal justice the only basis for the court's performing the collection of evidence should be presence of the request for the parties about it, so initiating judicial actions in order to obtain new evidence should be the task of the parties. The activeness of the court in performing judicial actions must be determined exclusively by the necessity of examining and assessing the evidence. The article proposes to introduce modifications in the Code of Criminal Procedure of the Russian Federation in order to remove the uncertainty of the court status existing at the current moment.

KEYWORDS. Competitiveness; court activeness; proofing; collection of evidence.

ARTICLE INFO. Received August 26, 2016; accepted September 13, 2016; available online September 26, 2016.
\end{abstract}

(C) В.А. Щербаков, 2016

\section{Baikal Research Journal}


Вопрос об условиях вынесения справедливого приговора представляет существенный интерес, прежде всего, с точки зрения организации уголовного процесса. Речь идет о состязательности уголовного судопроизводства, предполагающей такую организацию процессуальной деятельности, при которой разрешение уголовного дела происходит в результате спора равноправных сторон перед независимым судом.

В дореволюционной теории к необходимым признакам состязательности в уголовном процессе относились следующие:

- наличие в процессе сторон с противоположными материально-правовыми интересами, стоящих отдельно от суда;

- процессуальное равноправие сторон, участвующих в деле;

- освобождение суда от тех процессуальных функций, которые выполняются в процессе сторонами [1, с. 45$]$.

По мнению современных ученых-процессуалистов, суть состязательности в уголовном процессе может быть сведена к двум элементам - равноправие сторон и независимость суда, поскольку эти элементы «в совокупности образуют "несущую конструкцию” состязательного процесса. Они - принципы-максимы. Все другие, институционные, принципы состязательного судопроизводства могут быть логически выведены из двух этих фундаментальных начал» [2, с. 30].

Согласно принципу состязательности (ч. 3 ст. 15 Уголовно-процессуального кодекса РФ (УПК РФ)) суд, призванный разрешить спор сторон, не может выступать ни на стороне обвинения, ни на стороне защиты. Как правомерно отмечает Н. Ю. Литвинцева, именно благодаря беспристрастности суда, его выводы, положенные в основу приговора, обязаны быть наиболее близкими к справедливости как в правовом, так и в морально-нравственном смысле этого слова [3, с. 30]. Суд, оставаясь объективным и беспристрастным, контролирует правомерность поведения участников процесса, проверяет и оценивает представленные сторонами доказательства, создает объективные условия для вынесения справедливого решения.

Равенство сторон означает, что положение сторон в судебном процессе должно быть справедливо уравновешено, каждой стороне должна быть гарантирована равная процессуальная возможность изложить и обосновать перед независимым судом свою позицию по делу, в одну из задач которого входит обеспечение сторонам условий для свободного состязания.

Независимость суда является одним из главных условий обеспечения беспристрастности и справедливости правосудия. Как отмечает И. П. Попова, соблюдению принципа независимости судей способствует и реализация судом дискреционных полномочий, в том числе по собственной инициативе собирать доказательства, участвовать в их исследовании и давать им оценку свободно (ст. 15, 17, 88 УПК РФ) [3, с. 111-112].

В приведенном высказывании далеко небесспорным является утверждение о праве суда по собственной инициативе собирать доказательства, поскольку в этом отношении законодатель высказался не вполне определенно, и о роли суда в современном судопроизводстве до сих пор отсутствует единство мнений. В связи с этим представляется необходимым рассмотрение именно этого аспекта состязательности судебного процесса.

Так, проведенный анализ точек зрения ученых на природу положения суда в уголовном судопроизводстве показал неоднозначность подходов к определению его статуса в условиях реализации принципа состязательности. Наиболее дискуссионными в настоящее время являются вопросы, касающиеся, во-первых, правомерности отнесения суда к субъектам доказывания, во-вторых, установления степени и пределов активности суда в состязательном судопроизводстве и, в-третьих, допустимости в связи с этим осуществления судом собирания доказательств по собствен-

\section{Baikal Research Journal}

электронный научный журнал Байкальского государственного университета 
ной инициативе. Как верно отмечено А. А. Плашевской, разрешение этих вопросов связано с выработкой законодательно предусмотренного механизма, позволяющего суду не быть втянутым в состязание сторон, с одной стороны, и иметь возможность выносить обоснованный и справедливый приговор, с другой [4, с. 5].

Как отмечается В. И. Зажицким, под влиянием принципа состязательности сторон в нормах уголовно-процессуального закона двойственно определяются процессуальные полномочия суда как основного профессионального участника уголовного судопроизводства. Так, согласно требованию важнейшего элемента принципа состязательности сторон о разделении функций, обязанностью суда является лишь создание необходимых условий для реализации сторонами их прав и процессуальных обязанностей, предоставленных законом (ч. 2, 3 ст. 15, ч. 1 ст. 243 УПК РФ), что исключает активную роль суда в исследовании обстоятельств уголовного дела. В то же время, согласно ст. 17, ч. 1 ст. 74 , ч. 1 ст. 86 , ст. 87 УПК РФ, суд является субъектом доказывания, что, по справедливому мнению ученого, несовместимо с предыдущим предписанием [5, с. 6-7].

Следует признать, что оснований для подобного утверждения достаточно. Во-первых, ст. 85 УПК РФ определяет доказывание как собирание, проверку и оценку доказательств с целью установления обстоятельств, предусмотренных ст. 73 УПК РФ, определяющей предмет доказывания. В этой связи вполне обоснованной является позиция В. А. Лазаревой, указывающей, что, исходя из принципа презумпции невиновности, в доказывании нуждается только виновность лица в совершении преступления, поскольку УПК РФ не содержит требования доказывания невиновности - она презюмируется. Напротив, в том случае, когда не доказана виновность обвиняемого, происходит постановление оправдательного приговора и признание его невиновным (ч. 2, 3 ст. 302 УПК РФ). «Из этого следует, - заключает автор, - что доказывание - это деятельность только субъектов уголовного преследования, которые посредством собирания, проверки и оценки доказательств обязаны опровергнуть презумпцию невиновности" [6, с. 38-39]. Во-вторых, изложенное вступает в явное противоречие с принципом состязательности сторон, поскольку согласно ч. 3. ст. 15 УПК РФ суд не является органом уголовного преследования. Тем не менее, законодателем в нормативном перечне субъектов доказывания наряду с участниками уголовного судопроизводства со стороны обвинения (следователем, дознавателем и прокурором) назван и суд (ч. 1 ст. 86 УПК РФ), что, по справедливому замечанию В. А. Лазаревой, извращает роль суда в уголовном судопроизводстве, как независимого от сторон носителя судебной власти, призванного осуществлять правосудие [Там же, с. 39].

Сходной точки зрения придерживаются и другие ученые. По мнению А. Р. Белкина, суду на стадии судебного следствия принадлежит лишь функция исследования и оценки представленных сторонами доказательств, которая отнюдь не означает участие суда в доказывании. Суд не должен собирать доказательства, т. е. формировать доказательственную базу обвинения или защиты, поскольку его назначением является судить, а не доказывать [7, с. 58].

Противоположной позиции придерживается А. А. Власов, считающий достаточным основанием для признания суда субъектом доказывания то, что именно суд несет ответственность за доказывание, а иного быть не может, так как в случае обжалования решение может быть отменено [8, с. 19].

Представляется, что решение суда может быть отменено отнюдь не потому, что судом не доказаны обстоятельства, входящие в предмет доказывания, а потому, что суд ошибочно признал их доказанным. Как точно указывает В. А. Лазарева, если для следователя и прокурора суждение «установить событие преступления и виновность подсудимого», действительно, означает доказать обвинение, то в отношении

\section{Baikal Research Journal}


суда оно означает признать или не признать его доказанным [9, с. 43], поэтому дело суда - полно и всесторонне исследовать представленные сторонами доказательства, объективно оценить их и вынести приговор.

С. В. Корнакова основное отличие деятельности судьи от деятельности других профессиональных участников судебного следствия видит в том, что если деятельность сторон направлена на убеждение суда в обоснованности своих позиций посредством представления доказательств, то судья никого не обязан убеждать - суд, оставаясь беспристрастным и независимым, руководствуясь внутренним убеждением, законом и совестью (ч. 1 ст.17 УПК РФ), должен убедиться сам в доказанности или недоказанности версии обвинения на основании непосредственного исследования, проверки и оценки представленных сторонами доказательств [10, с. 75; 11, с. 94]. Версия обвинения о доказанности совершения преступления - всего лишь версия, которую, должен проверить «на прочность» (признать доказанным или недоказанным) суд в состязательном уголовном процессе. А значит, обязанность суда, как справедливо отмечает О. В. Баев, - оценивать достоверность версии каждой из состязающихся сторон с точки зрения достаточности и достоверности представленных доказательств, и по результатам этого выносить итоговое решение - отправлять правосудие $[12$, с. 21,25$]$.

С. А. Шейфер, являясь сторонником отнесения суда к субъектам доказывания, обосновывает свою позицию положениями уголовно-процессуального закона, которые предписывают суду собирать доказательства (ст. 86 УПК РФ), а также исследовать доказательства посредством проведения судебных действий (ст. 240 УПК РФ, ст. 287-290 УПК РФ), поэтому доказательства, по его мнению, собирает не только следователь, но и суд. При этом основным аргументом ученого является то, что результаты познавательной деятельности суда фиксируются в протоколе судебного заседания, и только после этого они становятся доказательствами [13, с. 40].

Как представляется, с приведенным утверждением можно не согласиться, как минимум, по двум причинам. Во-первых, как указывает сам автор, сведения о существенных обстоятельствах уголовного дела в условиях судебного разбирательства в большинстве случаев бывают получены «из тех же источников, из которых получил их следователь» [Там же], поэтому нет оснований считать судебное исследование этих доказательств повторным процессом их собирания. И, во-вторых, факт фиксации исследованных судом доказательств в протоколе судебного заседания также не означает их собирания исключительно судом, поскольку в этом документе отражаются все собранные в ходе предварительного расследования, представленные суду стороной обвинения и стороной защиты, а также полученные при их активном участии в ходе проведения судебного следствия доказательства, в том числе и те, которые не будут в дальнейшем положены в основу приговора, как отвергнутые судом по результату их проверки и оценки. Поэтому суд осуществляет не собирание, а исследование доказательств посредством судебных действий с целью их проверки и оценки на предмет относимости, допустимости, достоверности и достаточности для разрешения уголовного дела по существу. В этой связи представляется обоснованной позиция ученых, согласно которой суд в состязательном уголовном процессе является не субъектом, а адресатом доказывания [9, с. 39].

Таким образом, вопрос о том, является ли суд субъектом доказывания по уголовному делу, по сути, сводится к вопросу о роли суда - его активности или пассивности - в достижении достоверного знания об обстоятельствах, предусмотренных ст. 73 УПК РФ.

Следует отметить противоречивость точек зрения на возможность собирания доказательств по инициативе суда, которая существует как в процессуальной литературе, так и в позициях судов высшей инстанции.

\section{Baikal Research Journal}

электронный научный журнал Байкальского государственного университета 
Так, в определении от 6 марта 2003 г. № 104-О Конституционным Судом РФ указано, что согласно действующему уголовно-процессуальному закону собирание доказательств не является исключительно прерогативой сторон, но относится к полномочиям суда, реализуемым в порядке, установленном УПК РФ для производства судебного следствия ${ }^{1}$. Представляется, что приведенное решение Конституционного Суда РФ противоречит принципу состязательности уголовного судопроизводства, поскольку в нем оправдывается выполнение судом не свойственной ему функции обвинения.

В то же время в определениях Верховного Суда РФ достаточно часто встречается формулировка о том, что «в обязанности суда с учетом конституционного принципа осуществления судопроизводства на основе состязательности сторон сбор дополнительных доказательств не входит» ${ }^{2}$.

Так, в кассационном определении от 12 апреля 2007 г. по делу № 64-006-43 одним из оснований отмены приговора в отношении осужденного Сабирова Р. О. судебная коллегия указала, что «в обвинительном заключении при отрицании вины обвиняемого Сабирова в убийстве К. и в краже чужого имущества не приведено совокупности доказательств в предъявленном объеме обвинения (по ч. 1 ст. 105; ч. 1 ст. 158 УК РФ), не представлено их и стороной обвинения - государственным обвинителем суду в ходе судебного разбирательства. В обязанности суда в соответствии с конституционным принципом осуществления судопроизводства в РФ (ст. 123 Конституции РФ) на основе состязательности сторон не входит сбор дополнительных доказательств обвинения» ${ }^{3}$.

Такая же противоречивость во взглядах на роль суда в уголовном судопроизводстве прослеживается и в юридическом сообществе. Так, основным аргументом сторонников активной позиции суда в судебном процессе является то, что именно суд, а не государственный обвинитель или защитник, несет полную ответственность за принятое в результате судебного разбирательства решение, поэтому, по их мнению, суд не должен быть связан исключительно представленным сторонами обвинения и защиты доказательственным материалом [14, с. 65].

По мнению же противников активности суда в судебном разбирательстве, закрепленная в УПК РФ возможность собирания судом доказательств по собственной инициативе не соответствует его уголовно-процессуальной функции - разрешению уголовного дела - и противоречит принципу состязательности $[15$, с. 6]. Суд вообще не может и не должен вмешиваться в деятельность других участников процесса по собиранию доказательств (ч. 1 ст. 86 УПК РФ) [16, с. 73-74]. М. К. Гочияев вполне убедительно замечает, что именно отсутствие у суда инициативы в собирании и исследовании доказательств в судебном процессе, во-первых, исключает возможные подозрения в его необъективности и предвзятости и, во-вторых, предоставле-

\footnotetext{
${ }^{1}$ Об отказе в принятии к рассмотрению запроса Бокситогорского городского суда Ленинград-ской области о проверке конституционности части первой статьи 86 Уголовно-процессуального кодекса Российской Федерации : определение Конституц. Суда РФ от 6 марта 2003 г. № 104-О // СПС «КонсультантПлюс» .

${ }^{2}$ См.: Апелляционное определение Верховного Суда РФ от 26 августа 2014 г. по делу № 81-АПУ1427 // СПС «КонсультантПлюс»; Апелляционное определение Верховного Суда РФ от 22 августа 2014 г. по делу № 2-2/14 // Там же; Апелляционное определение Верховного Суда РФ от 3 октября 2013 г. по делу № 2-10/13 // Там же; Кассационное определение Верховного Суда РФ от 22 февраля 2013 г. по делу № 2-135/2012 // Там же; Кассационное определение Верховного Суда РФ от 13 декабря 2012 г. по делу № 2-86/12 // Там же; Кассационное определение Верховного Суда РФ от 22 ноября 2012 г. Дело № 60012-9 // Там же; Кассационное определение Верховного Суда РФ от 24 мая 2012 г. по делу № 2-31/12 // Там же; Кассационное определение Верховного Суда РФ от 12 мая 2011 г. по делу № 2-36/11 // Там же; Кассационное определение Верховного Суда РФ от 17 марта 2011 г. по делу № 2-129/2010 / / Там же; и др.

${ }^{3}$ Кассационное определение Судебной коллегии по уголовным делам Верховного Суда РФ от 12 апреля 2007 г. по делу 64-006-43 // Там же.
}

\section{Baikal Research Journal}

электронный научный журнал Байкальского государственного университета 
ние сторонам возможности самостоятельного исследования доказательств так, как они считают нужным, позволяет им быть уверенными в том, что их интересы представлены верно [17, с. 13].

Не стоит отрицать, что в приведенных утверждениях содержится рациональное зерно и категорически их отвергать несправедливо. Однако наиболее критикуемым в юридической литературе является то, что сторонники пассивной роли суда в судебном процессе суть состязательности видят в споре, когда «итоговое решение выносится в пользу того, кто лучше к спору готов» [18, с. 161].

По мнению Ю. К. Орлова, так называемая «чистая состязательность», уподобляющая суд беспристрастному арбитру в спортивной борьбе, присуждающему приз победителю, допустима лишь в такой судебной системе, где гражданин не обращается к государству, а борется с ним. Более того, пассивность и отстраненность суда от процессуального спора сторон обвинения и защиты означает отсутствие у него правовой ответственности за результат разрешения уголовного дела [19, с. 19-20]. «В уголовном судопроизводстве, - подчеркивает автор, - на первом месте всегда социальные цели и интересы, основной из которых является раскрытие преступлений, изобличение виновных, принятие мер к предупреждению преступлений» [20, с. 134]. Поэтому сущность состязательности должна состоять в гарантированности обеспечения судом справедливого и беспристрастного разрешения уголовного дела.

Представляется, что недопустимость сведения роли суда лишь к выполнению технических функций по обеспечению процедуры процесса и порядка в судебном заседании не должна вызывать сомнения, роль суда не может заключаться в молчаливом наблюдении за состязанием сторон и объявлении победителя. Активность суда не противоречит и действующему УПК РФ, в котором законодателем суду отведена роль отнюдь не пассивного арбитра. Суду в этом отношении законом предоставлены значительные возможности: задавать участникам судопроизводства вопросы в ходе их допросов (ст. 275, 277, 278 УПК РФ); вызывать по собственной инициативе для допроса эксперта, давшего заключение в ходе предварительного расследования (ст. 282 УПК РФ); назначать судебную экспертизу (ст. 283 УПК РФ); принимать решение об оглашении показаний участников процесса, данных ими на стадии предварительного расследования (ст. 276, 281 УПК РФ); исследовать и приобщать к материалам уголовного дела новые доказательства (ст. 286 УПК РФ); принимать решение об осмотре местности и помещения, о производстве следственного эксперимента, об освидетельствовании, об опознании (ст. 287, 288, 289, 290 УПК РФ); производить иные судебные действия по исследованию доказательств (ч. 1. ст. 240 УПК РФ).

Таким образом, можно констатировать отсутствие единства во взглядах ученых на роль суда в состязательном судопроизводстве. При этом важно отметить наличие возможностей для обоснования позиций как сторонников, так и противников активности суда в условиях судебного разбирательства нормами уголовно-процессуального закона. В этой связи Н. Ю. Литвинцева задает закономерный вопрос: «Каких действий ожидал от суда законодатель, определяя круг его правомочий? Предполагалась ли пассивная роль суда при активной равноправной деятельности сторон? Или же суд должен быть той «последней инстанцией», которая установит объективную картину преступления и накажет виновного в его совершении или оправдает невинного?» [3, с. 233]. Следует признать, что неоднозначность закрепления в уголовно-процессуальном законе процессуальных полномочий суда не позволяет в настоящее время со строгой определенностью ответить на эти вопросы.

Кроме этого, учитывая, что реализация судом полномочий по получению доказательств по своей инициативе (ст. 283, 285, 287-290 УПК РФ) не зависит от их содержания, поэтому могут быть получены не только оправдательные, но и обвинительные доказательства, что означает реализацию судом функции обвинения. Как обоснован-

\section{Baikal Research Journal}

электронный научный журнал Байкальского государственного университета 
но в связи с этим указывает О. Д. Кузнецова, подобная регламентация полномочий суда противоречит основному элементу принципа состязательности - отделению функции разрешения дела от функции обвинения. По мнению ученого, при оценке доказательств обвинения, полученных по инициативе суда при отсутствии ходатайства стороны обвинения, они должны признаваться недопустимыми, как добытые с нарушением ст. 15 УПК РФ, выражающимся в принятии судом на себя функции обвинения [21, с. 18-19]. Поэтому принцип состязательности требует от суда полного отказа от действий, которые могут быть оценены как обвинительные.

В этой связи заслуживают поддержки выводы ученых, считающих, что для последовательной реализации принципа состязательности уголовного судопроизводства инициирование производства судебных действий в целях пополнения доказательственной базы должно быть исключительно задачей сторон, поэтому единственным основанием осуществления судом собирания доказательств должно быть наличие ходатайства о том стороны, либо невозможность или затруднительность для нее самостоятельного получения данного доказательства [4, с. 14].

Для обеспечения справедливой процедуры и результата уголовно-процессуальной деятельности представляется не только допустимой, но и необходимой активная деятельность суда по выяснению у сторон наличия заявлений и ходатайств. Подобный подход к деятельности суда при разрешении уголовных дел согласуется и с позицией Верховного Суда РФ, который отражает в своих решениях допустимость активности суда по собиранию доказательств наличием ходатайства сторон.

Так, в кассационном определении от 14 июня 2005 г. по делу № 666-005-24 судебная коллегия Верховного суда РФ указала, что «...ссылка кассационных жалоб на то, что в судебном заседании не допрошены и суд не вызвал для допроса в качестве новых свидетелей, не свидетельствует о нарушении закона, поскольку конкретных фамилий никто из осужденных не называл и ходатайств об их допросе не заявлял, а в обязанности суда с учетом конституционного принципа состязательности сторон - сбор дополнительных доказательств не входит» ${ }^{4}$.

Позиция Конституционного Суда РФ по этому поводу выражена в определении от 18 июня 2004 г. № 206-О 5 , согласно которому к ведению суда относится проверка и оценка правильности и обоснованности сделанных сторонами обвинения и защиты выводов по существу обвинения. Конституционный принцип состязательности и равноправия сторон не освобождает суд от обязанности в рамках предоставленных законом полномочий по исследованию доказательств, обеспечения справедливого и беспристрастного разрешения дела по существу. Осуществление судом функции правосудия с необходимостью предполагает наличие у него обязанности проверять и оценивать имеющимися в уголовном деле либо предоставленные сторонами доказательства с точки зрения их относимости, допустимости и достоверности, в том числе путем производимого по ходатайству сторон или по своей инициативе получения и исследования в рамках обвинения иных доказательств, подтверждающих или опровергающих доказательство, проверяемое судом. Иное положение лишило бы суд возможности объективной оценки позиций сторон и устранения возникающих при рассмотрении уголовных дел сомнений в их обоснованности, а, значит, не обеспечило бы независимость и беспристрастность суда при отправлении правосудия.

В этой связи обоснованной представляется позиция М. Е. Пучковской, которая утверждает, что «в законе должно прозвучать, для каких целей судом собираются

${ }^{4}$ URL : http://sudact.ru/vsrf/doc/5D6W5QOEfllR/.

${ }^{5}$ По жалобе гражданина Корковидова Артура Константиновича на нарушение его конституционных прав статьями 195, 198 и 203 Уголовно-процессуального кодекса Российской Федерации : определение Конституц. Суда РФ от 18 июля 2004 г. № 206-О // СПС «КонсультантПлюс» .

\section{Baikal Research Journal}

электронный научный журнал Байкальского государственного университета 
доказательства - для проверки уже имеющихся доказательств, но не для восполнения доказательственной базы» [22, с. 136].

Примером правомерности проявления активности судом в целях проверки имеющихся в деле доказательств служит определение Конституционного Суда РФ от 18 июня 2004 г. № 204-О: «Как следует из представленных материалов, в ходе рассмотрения уголовного дела по обвинению Ц.Н. Будаева в совершении преступления, предусмотренного пунктом “б” ч. 3 ст. 159 “Мошенничество” УК РФ, Таганский районный суд г. Москвы по собственной инициативе назначил судебно-бухгалтерскую, повторную строительно-технологическую и судебно-почерковедческую экспертизы. Поводом для их назначения послужило, соответственно, взаимное противоречие содержащихся в материалах дела аудиторских заключений, отсутствие в постановлении следователя о назначении строительно-технологической экспертизы подписки эксперта в том, что он предупрежден об уголовной ответственности за дачу заведомо ложного заключения, а также оспаривание подсудимым принадлежности ему подписи в исследуемых по делу документах» ${ }^{6}$. Конституционный Суд РФ признал действия суда законными и обоснованными.

Таким образом, если имеющиеся в деле и представленные сторонами доказательства содержат существенные противоречия, не позволяющие однозначно судить ни о виновности, ни о невиновности подсудимого, суд в целях устранения противоречий имеет право по собственной инициативе проводить судебные действия по проверке этих доказательств на предмет их достоверности и достаточности для справедливого разрешения дела. Безусловно, суд не должен собирать доказательства, восполняя недостатки деятельности органов предварительного расследования, но проверка и оценка имеющихся в деле доказательств отнюдь не означает переложение бремени доказывания на суд.

В этом отношении справедливым является вывод Н. П. Кирилловой о том, что законодатель должен таким образом сформулировать полномочия суда, чтобы исключить выполнение им функций обвинения или защиты, а потому если активность суда путем проведения судебных действий обусловлена необходимостью проверки и оценки доказательств, то деятельность суда соответствует принципу состязательности. В том же случае, когда активность суда продиктована целью укрепления позиций стороны обвинения или защиты, создания доказательственной базы, то такая деятельность не согласуется с принципом состязательности [23, с. 139].

Именно суд является основным субъектом оценки доказательств и все, представляемые сторонами в ходе судебного следствия доказательства, адресованы суду. В связи с этим следует согласиться с утверждением А. А. Плашевской, считающей, что законодатель при определении процессуального статуса суда должен был исходить из закрепленного в ст. 15 УПК РФ принципа состязательности и осуществляемой им единственной функции разрешения дела, поэтому полномочия суда в ходе судебного следствия должны определяться отдельно от полномочий иных процессуальных участников уголовного судопроизводства, как это сделано в разд. II гл. 5 УПК РФ [4, с. 14].

Для реализации указанной рекомендации необходимо внести в уголовно-процессуальный закон некоторые изменения, которые заключаются в следующем:

- изменить формулировку ч. 1 ст. 86 УПК РФ путем исключения суда из нормативного перечня субъектов собирания доказательств;

- дополнить ст. 86 УПК РФ нормой 1.1 следующего содержания:

${ }^{6}$ Об отказе в принятии к рассмотрению жалобы гражданина Будаева Цогта Нацагдоржевича на нарушение его конституционных прав частью второй статьи 283 Уголовно-процессуального кодекса Российской Федерации : определение Конституц. Суда РФ от 18 июня 2004 г. № 204-О // СПС «КонсультантПлюс».

\section{Baikal Research Journal}

электронный научный журнал Байкальского государственного университета 
«В ходе судебного следствия суд оказывает содействие сторонам в собирании доказательств посредством разрешения их ходатайств о производстве процессуальных действий. Суд вправе по собственной инициативе производить указанные в настоящем Кодексе судебные действия исключительно в целях проверки и оценки представленных сторонами доказательств» .

Как представляется, данные изменения позволят не только лишить основы непродуктивные споры относительно положения суда в судебном процессе и устранить имеющую место в настоящее время неопределенность его статуса, но и обеспечить выполнение судом обязанности вынесения законных и обоснованных и справедливых решений.

\section{Список использованной литературы}

1. Духовской М. В. Русский уголовный процесс / М. В. Духовской. - М. : Изд. кн. склада М. В. Клюкина, 1905. - 472 с.

2. Рябцева Е. В. Деятельность и положение суда в состязательном уголовном судопроизводстве : автореф. дис. ... канд. юрид. наук : 12.00 .09 / Е. В. Рябцева. - Воронеж, 2005. - 24 с.

3. Принципы современного российского уголовного судопроизводства : монография / под ред. И. В. Смольковой. - М. : Юрлитинформ, 2015. - 358 с.

4. Плашевская А. А. Собирание судом доказательств при рассмотрении дела по первой инстанции в уголовном процессе России : автореф. дис. ... канд. юрид. наук : 12.00.09 / А. А. Плашевская. - Томск, 2006. - 27 с.

5. Зажицкий В. И. Об основных направлениях совершенствования Уголовно-процессуального кодекса Российской Федерации / В. И. Зажицкий // Вестник Академии Генеральной прокуратуры Российской Федерации. - 2011. - № 3 (23). - С. 3-9.

6. Лазарева В. А. Прокурор в уголовном процессе : учеб. пособие / В. А. Лазарева. - Самара : Изд-во Самар. ун-та, 2010. - 223 с.

7. Белкин А. Р. Теория доказывания в уголовном судопроизводстве / А. Р. Белкин. M. : Норма, 2005. $-528 \mathrm{c}$.

8. Власов А. А. Особенности доказывания в судопроизводстве : науч.-практ. пособие / А. А. Власов, И. Н. Лукьянова, С. В. Некрасов. - М. : Экзамен, 2004. - 318 с.

9. Лазарева В. А. Проблемы доказывания в современном уголовном процессе России : учеб. пособие / В. А. Лазарева. - Самара : Самар. ун-т, 2007. - 303 с.

10. Корнакова С. В. Об установлении истины в уголовном судопроизводстве России в свете принципа состязательности уголовного процесса / С. В. Корнакова // Юридическая наука и правоохранительная практика. - 2009. - № 1 (7). - С. 73-79.

11. Корнакова С. В. Состязательность - условие равноправия сторон в уголовном судопроизводстве / С. В. Корнакова // Юридическая наука и правоохранительная практика. 2009. 一 № 1 (7). - С. 92-97.

12. Баев О. Я. Законопроект «Об объективной истине в уголовном судопроизводстве» и возможные последствия его принятия / О. Я. Баев // Библиотека криминалиста. - 2012. № 4 (5). - C. 19-32.

13. Шейфер С. А. Предварительное и судебное следствие по УПК РФ: проблемы соотношения / С. А. Шейфер / / Проблемы обеспечения прав участников процесса по новому Уголовно-процессуальному кодексу Российской Федерации : материалы Межрегион. науч.-практ. конф. Самара, 18-19 дек. 2002 г. - Самара : Изд-во Самар. ун-та, 2003. - С. 31-41.

14. Кузьмина О. В. Состязательность уголовного судопроизводства как способ достижения истины / О. В. Кузьмина // Бюллетень Международной ассоциации содействия правосудию. -2015 . - № 1. - С. 59-65.

15. Уголовный процесс : учебник / под общ. ред. А. В. Смирнова. - 4-е изд., перераб. и доп. - М. : КноРус, 2008. - 704 с.

16. Соколовская Н. С. Роль суда в состязании сторон по уголовно-процессуальному законодательству Российской Федерации : автореф. дис. ... канд. юрид. наук : 12.00 .09 / Н. С. Соколовская. - Томск, 2005. - 22 с.

17. Гочияев М. К. Судебное следствие как объективная основа законного и обоснованного приговора : автореф. дис. ... канд. юрид. наук : 12.00.09 / М. К. Гочияев. - Краснодар, 2006. -24 c.

\section{Baikal Research Journal}


18. Брестер А. А. Начало, форма и метод российского уголовного процесса : дис. ... канд. юрид. наук : 12.00.09 / А. А. Брестер. - Красноярск, 2013. - 219 с.

19. Орлов Ю. К. Основы теории доказательств в уголовном процессе Ю. К. Орлов. - М. : Проспект, 2000. - 144 с.

20. Орлов Ю. К. Размышления об истине в уголовном процессе / Ю. К. Орлов // Вестник Волгоградской академии МВД России. - 2016. - № 3 (36). - С. 132-138.

21. Кузнецова О. Д. Роль суда в состязательном процессе и проблемы практической реализации функции разрешения дела / О. Д. Кузнецова // Российский судья. -2004. № 8. - С. 17-21.

22. Пучковская М. И. Исправление судом следственных ошибок на стадии предварительного расследования и при производстве в суде первой инстанции : дис. ... канд. юрид. наук : 12.00.09 / М. И. Пучковская. - Красноярск, 2003. - 187 с.

23. Кириллова Н. П. Процессуальные функции профессиональных участников состязательного судебного разбирательства уголовных дел / Н. П. Кириллова. - СПб. : Изд-во юрид. фак. С.-Петерб. гос. ун-та, 2007. - 408 с.

\section{References}

1. Dukhovskoy M. V. Russkii ugolovnyi protsess [Russian criminal procedure]. Moscow, M. V. Klyukin Publ., 1905. 472 p.

2. Ryabtseva E. V. Deyatel'nost' i polozhenie suda v sostyazatel'nom ugolovnom sudoproizvodstve. Avtoref. Kand. Diss. [Activity and position of the court in adversary criminal procedure. Cand. Diss. Thesis]. Voronezh, 2005. 24 p.

3. Smol'kova I. V. (ed.). Printsipy sovremennogo rossiiskogo ugolovnogo sudoproizvodstva [Principles of modern Russian criminal procedure]. Moscow, Yurlitinform Publ., 2015. 358 p.

4. Plashevskaya A. A. Sobiranie sudom dokazatel'stv pri rassmotrenii dela po pervoi instantsii $v$ ugolovnom protsesse Rossii. Avtoref. Kand. Diss. [Court collecting proofs in examining first instance cases in Russia's criminal procedure. Cand. Diss. Thesis]. Tomsk, 2006. 27 p.

5. Zazhitsky V. I. General tendencies in perfection of Criminal Procedure Code of the Russian Federation. Vestnik Akademii General'noi prokuratury Rossiiskoi Federatsii = Bulletin of Academy of the RF Prosecutor General's Office, 2011, no. 3 (23), pp. 3-9. (In Russian).

6. Lazareva V. A. Prokurorv ugolovnom protsesse [Prosecutor in criminal procedure]. Samara State University Publ., 2010. 223 p.

7. Belkin A. R. Teoriya dokazyvaniya $v$ ugolovnom sudoproizvodstve [Theory of proving in criminal procedure]. Moscow, Norma Publ., 2005. 528 p.

8. Vlasov A. A., Luk'yanova I. N., Nekrasov S. V. Osobennosti dokazyvaniya v sudoproizvodstve [Features of proving in judicial proceeding]. Moscow, Ekzamen Publ., 2004. 318 p.

9. Lazareva V. A. Problemy dokazyvaniya v sovremennom ugolovnom protsesse Rossii [Problems of proving in Russia's present-day criminal procedure]. Samara State University Publ., 2007. $303 \mathrm{p}$.

10. Kornakova S. V. On establishing the truth in Russia's criminal procedure in terms of the principle of criminal procedure adversariality. Yuridicheskaya nauka i pravookhranitel'naya praktika = Legal Science and Law Enforcement Practice, 2009, no. 1 (7), pp. 73-79. (In Russian).

11. Kornakova S. V. Adversariality as a condition of equality of the parties in criminal procedure. Yuridicheskaya nauka i pravookhranitel'naya praktika = Legal Science and Law Enforcement Practice, 2009, no. 1 (7), pp. 92-97. (In Russian).

12. Bayev O. Ya. The Bill «On objective truth in criminal proceedings» and possible consequences of its adoption». Rossiiskii sud'ya = Russian Judge, 2012, no. 4 (5), pp. 19-32. (In Russian).

13. Sheifer S. A. Preliminary and judicial examination in terms of the RF Criminal and Procedural Code: problems of correlation. Problemy obespecheniya prav uchastnikov protsessa po novomu Ugolovno-protsessual'nomu kodeksu Rossiiskoi Federatsii. Materialy Mezhregional'noi nauchno-prakticheskoi konferentsii. Samara, 18-19 dek. $2002 \mathrm{~g}$. [Problems of providing right for participants of the procedure according to the new Code of Criminal Procedure of the Russian Federation. Materials of Inter-Regional Research Conference. Samara, December 18-19, 2002]. Samara State University Publ., 2003, pp. 31-41. (In Russian).

14. Kuz'mina O. V. Adversariality of criminal procedure as a way of attaining the truth. Byulleten' Mezhdunarodnoi assotsiatsii sodeistviya pravosudiyu = Bulletin of International Union of Assistance of Justice, 2015, no. 1, pp. 59-65. (In Russian).

\section{Baikal Research Journal}


15. Smirnova A. V. (ed.). Ugolovnyi protsess [Criminal Process]. $4^{\text {th }}$ ed. Moscow, KnoRus Publ., 2008. 704 p.

16. Sokolovskaya N. S. Rol' suda v sostyazanii storon po ugolovno-protsessual'nomu zakonodatel'stvu Rossiiskoi Federatsii. Avtoref. Kand. Diss. [The role of court in adversariality of the parties according to the criminal and procedural legislation of the Russian Federation. Cand. Diss. Thesis]. Tomsk, 2005. 22 p.

17. Gochiyaev M. K. Sudebnoe sledstvie kak ob»ektivnaya osnova zakonnogo i obosnovannogo prigovora. Avtoref. Kand. Diss. [Court investigation as an objective basis of legal and justified sentence. Cand. Diss. Thesis]. Krasnodar, 2006. 24 p.

18. Brester A. A. Nachalo, forma i metod rossiiskogo ugolovnogo protsessa. Kand. Diss. [Beginning, form and method of Russian criminal proceeding. Cand. Diss.]. Krasnoyarsk, 2013. 219 p.

19. Orlov Yu. K. Osnovy teorii dokazatel'stv $v$ ugolovnom protsesse [Basics of proof theory in criminal proceeding]. Moscow, Prospekt Publ., 2000. 144 p.

20. Orlov Yu. K. Speculations on the truth in criminal proceeding. Vestnik Volgogradskoi akademii MVD Rossii = Bulletin of Volgograd Academy of the Russian Internal Affairs Ministry, 2016, no. 3 (36), pp. 132-138. (In Russian).

21. Kuznetsova O. D. The role of court in adversary system process an problems of practical implementing the function of solving the case. Rossiiskii sud'ya = Russian Judge, 2005, no. 8, pp. 17-21. (In Russian).

22. Puchkovskaya M. I. Ispravlenie sudom sledstvennykh oshibok na stadii predvaritel'nogo rassledovaniya i pri proizvodstve $v$ sude pervoi instantsii. Kand. Diss. [Court correcting cases of mistaken identity at the stage of preliminary investigation and in hearing in the first-instance court. Cand. Diss.]. Krasnoyarsk, 2003. 187 p.

23. Kirillova N. P. Protsessual'nye funktsii professional'nykh uchastnikov sostyazatel'nogo sudebnogo razbiratel'stva ugolovnykh del [Procedural functions of professional participants of adversarial juridical examination of criminal cases]. Saint Petersburg State University Publ., 2007. $408 \mathrm{p}$.

\section{Информация об авторе}

Щербаков Владилир Александрович - заместитель прокурора, прокуратура г. Новоалтайска Алтайского края, 658080, г. Новоалтайск, ул. Красногвардейская, 8, e-mail: law-ira@mail.ru.

\section{Author}

Vladinmir A. Shcherbakov - Deputy Prosecutor, Novoaltaisk Prosecutor's Office, 8 Krasnogvardeyskaya, 658080, Novoaltaisk, Altai Territory, Russian Federation; e-mail: law-ira@mail.ru.

\section{Библиографическое описание статьи}

Щербаков В. А. Состязательность уголовного судопроизводства: роль суда в ее обеспечении / В. А. Щербаков / / Baikal Research Journal. — 2016. — T. 7, № 5. — DOI : 10.17150/2411$\underline{6262.2016 .7(5) .17 .}$

\section{Reference to article}

Shcherbakov V. A. Adversary system of criminal proceedings: court's role in its provision. Baikal Research Journal, 2016, vol. 7, no. 5. DOI : $\underline{10.17150 / 2411-6262.2016 .7(5) .17 .}$ (In Russian).

\section{Baikal Research Journal}

